$\xi=-1$

\title{
The Relationship between Knowledge for Customer and Service Quality on Customer Satisfaction: A Study on UniKL MITEC Student Services
}

\author{
Khairul Firdaus Adrutdin ${ }^{1 *}$, Azlan Ali $^{2}$, Sallaudin Hassan ${ }^{3}$, Jimisiah Jaafar $^{4}$, \\ Nur Syafiqah A Rahim ${ }^{5}$, Muhammad Imran Qureshi ${ }^{6}$ \\ ${ }^{1}$ Universiti Kuala Lumpur, Malaysian Institute of Industrial Technology, Johor, khairulfirdaus@ unikl.edu.my \\ ${ }^{2}$ University College Technology Sarawak, Sibu \\ 3,4,5,6 Universiti Kuala Lumpur, Malaysian Institute of Industrial Technology, Johor \\ *Email: khairulfirdaus@unikl.edu.my
}

\begin{abstract}
Knowledge for customer roles $(\mathrm{KC})$ in student services is essentially very much important since the linkage of knowledge creation, sharing, dissemination and acquisition would be the value created for the customers. One of the important elements of customer knowledge (CK) is knowledge for customer roles (KC) and it reflects on how the process of knowledge transfer and exchange are conducted for the benefits of customer satisfaction (CS). This study aims to discuss on the relationship of knowledge for customer roles (KC) and service quality dimensions (SQ) on customer satisfaction (CS) in student services environment. In depth study on the customer knowledge (CK) dimension will be conducted in order to identify the level of knowledge of customers on student services and how the process of knowledge transfer and exchange are taking place. The study of service quality dimensions (SQ) in the student services is also conducted in order to identify the element of knowledge transfer and exchange that resides in the service quality RATER dimensions and how it relates to the knowledge for customer roles (KC) and customer satisfaction (CS). In conclusion, the construct of knowledge for customer roles (KC) relationship with the service quality dimensions (SQ) and customer satisfaction (CS) is critically assessed and the empirical studies are to be examined so as to assess on the obtained relationships.
\end{abstract}

Keywords: Service quality, customer knowledge, customer satisfaction, knowledge for customer, student services.

\section{Introduction}

The importance of customer satisfaction (CS) has been highlighted by many researchers and academicians all around the world. Satisfaction is an overall customer attitude or behaviour towards a service provider or an emotional reaction towards the difference between what customers expect and what they receive regarding the fulfilment of some desires and goals [1][2]. In the new era of generation nowadays, the importance of customer satisfaction is paramount as it greatly influences customers' repurchases whereas dissatisfaction is seen as a primary reason for customers' intention to switch. Satisfied customers are most likely to share their experiences with other few people around them. The importance of customer satisfaction cannot be dismissed because happy customers feed the companies' sustainability. Thus, in order to meet customer expectations, the organizations should take up a more comprehensive management approach. There is no doubt that companies nowadays have realized the significance of having customer focused and the uses of knowledge based strategies to reach to their customers could be the new strategy. As such, the application of knowledge for customer roles (KC) and its relationship with service quality (SQ) are of the relatively effective approaches in facilitating the move of the organization towards putting customer as the first priority.

Customer satisfaction (CS) is significantly and positively associated with customer loyalty. Customer satisfaction can be seen as one of the main instruments that ensure the existence and survival of business organizations. It is very important for the business organizations to consider offering what the customers want rather than offering quality goods and services which may not meet up with the customers' expectations. Customer satisfaction can be said to be in existence when the expectations of the customers are met or surpassed by the services or products of a business organization. In order to maintain the business through the satisfaction of customer, the application of customer knowledge function and its integration with service quality has to be measured in every organization.

In the context of student services, its wider attention range of services has made it inevitable for the inclusion of customer satisfaction (CS) and knowledge for customer roles (KC). Student service can be regarded as part of the educational process to elicit the students' perceptions and experience of facilities, programmes and services [3]. As part of the satisfaction in the higher education institutes, the students services is the measure of the effectiveness 
where the universities are working towards the plans for the future sustainability. As such, the fulfilment of customer satisfaction though the use of service quality dimensions (SQ) has long been in practice where the gap between customer expectations and perceptions are identified and analysed accordingly. It was also mentioned that identifying the values, attitudes and expectations of students are essentially important in order to ensuring quality service in higher education [3]. Therefore, in a higher learning institutions noble duty to fulfilling the societal needs, delivering of the knowledge and understanding of all related student services to the students is as well important and should not be taken for granted as this would in a way affect their satisfaction.

\section{Background of Studies}

Universiti Kuala Lumpur (UniKL) as one of the Malaysian leading technical universities was established back in 2002 is a wholly owned institution by Majlis Amanah Rakyat (MARA). UniKL with its14 branch institutes offer various foundation, diploma, undergraduate and postgraduate programmes and these institutes are strategically located all over peninsular Malaysia. At present, graduates of UniKL have successfully established their careers or become successful entrepreneurs in local and international arena. One of the institutes that are under the umbrella of UniKL is Malaysian Institutes of Industrial Technology (MITEC) and is the youngest institute established in 2008. Located at the heart of industrial surroundings in Bandar Seri Alam and Pasir Gudang, it offers good range of quality programs that cater for the industria needs. At present there are four dedicated programs namely Bachelor of Industrial Logistics, Bachelor of Engineering Technology in Quality Engineering, Bachelor of Engineering Technology in Facilities Maintenance and Bachelor of Engineering Technology in Instrumentation and Control Engineering. The current enrolment is reaching to 2,200 students and the institute is working relatively hard to achieve its maximum capacity of 3,000 students' population. It is this desire that should propel the institute to embark on its continual journey for quality services rendered to the students so as to gain the customer satisfaction testimonial.

\subsection{RATIONALE OF STUDIES IN UNIKL MITEC}

Customer satisfaction in student services is closely linked to the students increasing demand and the perception over the quality of services rendered. The needs for using the student services are inevitable since most of the students' activities would need the support from the related student services section. This has made the students as a primary consumer of student services and the fundamental aspect of quality service should be in place. As a result, responses on the market mechanism for quality improvements are under way and it is important for the institutes to be able to recognise the thorough understanding of the needs of the students as a starting point for improving the services [4].

As for the case of UniKL MITEC, the student services falls under the close supervision of Student Development and Campus Lifestyle Department. It consists of two sections namely Student Development that covers the aspect of teaching and learning as well as student activities and character building while Campus Lifestyle would look into the matters of student services which includes the aspect of welfare, governance, hostel, loan application as well as sports activities. All of these aspects of services are delivered to the students accordingly and in a manner that require affective management of student services. As such, the application of good service quality dimensions (SQ) together with the knowledge for customer roles (KC) should be made as an integrated component for the process of continual improvisation

\section{Knowledge for Customer Roles}

Customer knowledge can be referred to as the process of understanding the customers' current and future needs and preferences through the interaction, observation and analysis of their demand and purchase behaviour [5][6]. It is more on acquiring the valuable information that surrounds the customers that could help to provide new business direction and strategy. On the other hand, the level of customer knowledge is a contributing factor to which extent the customer process and analyse the product or service related features [7].

The customer knowledge can be classified into three components namely knowledge for customers, knowledge about customers and knowledge from customers [8][9][10][11][12]. The essence of customer knowledge can be summarised as below Table 1.1. Customer knowledge in this regard is a valuable asset to an organization where it is acquired for the purpose of improving of the products or service offered in the market place.

Table 1: Customer knowledge items

\begin{tabular}{|c|c|}
\hline $\begin{array}{c}\text { Customer } \\
\text { Knowledge } \\
\text { Items }\end{array}$ & Definition \\
\hline $\begin{array}{l}\text { Knowledge } \\
\text { about } \\
\text { customers } \\
\text { (KAC) }\end{array}$ & $\begin{array}{l}\text { Customers' background, motivation, expectation and pref- } \\
\text { erences on products or services. } \\
\text { Customers' past, present and future needs, desire, taste and } \\
\text { trends. } \\
\text { Information regarding the customers purchases, payment, } \\
\text { motivation, habits and demand pattern. }\end{array}$ \\
\hline $\begin{array}{l}\text { Knowledge } \\
\text { for cus- } \\
\text { tomers } \\
\text { (KC) }\end{array}$ & $\begin{array}{l}\text { Customers' needs for knowledge on products and services. } \\
\text { In support for customers' decision making and assist in } \\
\text { their buying cycle. } \\
\text { Information or knowledge on product or service that is } \\
\text { given to the customers upon their utilisation or usage. }\end{array}$ \\
\hline $\begin{array}{l}\text { Knowledge } \\
\text { from cus- } \\
\text { tomers } \\
\text { (KFrC) }\end{array}$ & $\begin{array}{l}\text { Customers' information and knowledge sharing. } \\
\text { Knowledge acquisition from customers for product and } \\
\text { service enhancement. } \\
\text { Information or knowledge that the customer shares with the } \\
\text { company through their feedbacks. }\end{array}$ \\
\hline
\end{tabular}

Customer knowledge can also be further dissected into four dimensions namely objective, subjective, specific and general knowledge where each of the components are expected to be correlated [13]. The details can be further explained in Table 1.2 below. These dimensions of customer knowledge are important since these signify the level of customer knowledge on the services and products offered, which in this case is the student services offered and delivered to the students.

Table 2: Dimensions of Customer knowledge

\begin{tabular}{|c|l|}
\hline $\begin{array}{c}\text { Customer } \\
\text { Knowledge } \\
\text { Items }\end{array}$ & \multicolumn{1}{c|}{ Definition } \\
\hline $\begin{array}{c}\text { Objective } \\
\text { knowledge }\end{array}$ & $\begin{array}{l}\text { Measure of how much factual knowledge a consumer has } \\
\text { about products, their attributes, and linkages between differ- } \\
\text { ing product attributes and their relationship to performance. }\end{array}$ \\
\hline $\begin{array}{c}\text { Subjective } \\
\text { knowledge }\end{array}$ & $\begin{array}{l}\text { Measures consumers' perceptions about how much they } \\
\text { think they know about a product. }\end{array}$ \\
\hline $\begin{array}{c}\text { Specific } \\
\text { knowledge }\end{array}$ & More detailed type of knowledge than general knowledge. \\
\hline $\begin{array}{c}\text { General } \\
\text { knowledge }\end{array}$ & $\begin{array}{l}\text { General (basic) level knowledge comprises knowledge } \\
\text { about the shared features of a product class, including in- } \\
\text { formation about the product group, and the potential bene- } \\
\text { fits/risks of the products belonging to it. }\end{array}$ \\
\hline
\end{tabular}


Generally, the focus of the study will be on the operational aspect of knowledge for customer roles (KC) in the student services area of which how it should be able to ensure that it can deliver its role for the purpose of information needs [14][15][16], problem solving [14][16] and customer education [15][16]. These three purposes should be closely related to service quality dimensions (SQ) since it can be the relevant platform to the transfer of knowledge and information on student services effectively.

\subsection{Classification of Knowledge}

Generally, types of knowledge are divided into four as presented in the Table 3

\begin{tabular}{|c|l|}
$\begin{array}{c}\text { Types of } \\
\text { Knowledge }\end{array}$ & \multicolumn{1}{c|}{ Explanation } \\
\hline $\begin{array}{c}\text { Internal } \\
\text { and Exter- } \\
\text { nal } \\
\text { Knowledge }\end{array}$ & $\begin{array}{l}\text { The sources of knowledge that either come from the inside } \\
\text { or outside of the organisation. } \\
\text { The internal sources can come from the company reposito- } \\
\text { ries while the external sources can be sought from internet } \\
\text { or other companies' experts. }\end{array}$ \\
\hline $\begin{array}{c}\text { Theoretical } \\
\text { and Practi- } \\
\text { cal }\end{array}$ & $\begin{array}{l}\text { The theoretical knowledge focuses more on the intellectual } \\
\text { and descriptive discourse while the practical knowledge } \\
\text { varies in the abilities and skills. } \\
\text { Knowledge } \\
\text { The practical knowledge can be gained from learning by } \\
\text { basis of communication of knowledge. }\end{array}$ \\
\hline $\begin{array}{c}\text { Individual } \\
\text { and Collec- } \\
\text { tive }\end{array}$ & $\begin{array}{l}\text { Individual knowledge is the knowledge held by the indi- } \\
\text { viduals in an organisation. } \\
\text { Collective knowledge is derived through the communica- } \\
\text { tion and interaction among the employees in the organisa- } \\
\text { Knowledge }\end{array}$ \\
\hline $\begin{array}{c}\text { Tacit and } \\
\text { Explicit } \\
\text { Knowledge }\end{array}$ & $\begin{array}{l}\text { Resides within the individuals' mind which is normally } \\
\text { hidden and difficult to be communicated. } \\
\text { Knowledge that can be articulated, communicated and } \\
\text { therefore, documented and shared across the organisation. }\end{array}$ \\
\hline
\end{tabular}

In terms of knowledge categorization, the most widely accepted is the tacit and explicit category [17][18][19]. Therefore, this study will also be focusing on the dimension of tacit and explicit knowledge and its relation to the customer satisfaction. It is can be further discussed in Table 4 below.

Table 4: Explicit and Tacit knowledge

\begin{tabular}{|c|c|}
\hline Explicit Knowledge & Tacit Knowledge \\
\hline Articulated. & Unarticulated. \\
\hline Codified. & $\begin{array}{c}\text { Hidden and not easily represented via } \\
\text { electronics medium. }\end{array}$ \\
\hline Documented and transferrable & Undocumented and personal. \\
\hline $\begin{array}{c}\text { Stored in external data bases } \\
\text { and other various forms. }\end{array}$ & $\begin{array}{c}\text { Stored within the individual mind, } \\
\text { perception, judgment and behaviour. }\end{array}$ \\
\hline Not owned by individuals. & Owned by individuals. \\
\hline
\end{tabular}

\section{Conceptual Relationship Matrix}

Based on the service quality dimensions (SQ) and knowledge for customer roles (KC), the conceptual relationship matrix in student services as a whole is derived as per Table 5 . Service quality dimensions (SQ) namely reliability, tangibility, responsiveness, empathy and assurance would be the dimensions adopted and combined with the knowledge for customer roles (KC) in assisting to increase student knowledge in student services aspects. However, for the purpose of this study, the dimensions of service quality are grouped into three components namely reliability, tangibility and competence. The items of empathy, assurance and responsiveness are bundled together under the component of competence. Table 1.5 further explains on the proposed conceptual relationship matrix between service quality dimensions (SQ) and knowledge for customer roles $(\mathrm{KC})$.

Table 5: Conceptual Relationship Matrix

\begin{tabular}{|c|l|l|l|}
\hline $\begin{array}{l}\text { Service } \\
\text { Quality }\end{array}$ & Info Needs & Problem Solving & $\begin{array}{l}\text { Customer Educa- } \\
\text { tion }\end{array}$ \\
\hline Reliability & $\begin{array}{l}\text { Reliability } \\
\text { dimension } \\
\text { could help } \\
\text { to achieve } \\
\text { and increase } \\
\text { the info } \\
\text { needs of } \\
\text { customers }\end{array}$ & $\begin{array}{l}\text { Reliability dimen- } \\
\text { sion could assist on } \\
\text { the customer prob- } \\
\text { lem solving. }\end{array}$ & $\begin{array}{l}\text { Reliability dimen- } \\
\text { sion could assist on } \\
\text { the customer edu- } \\
\text { cation. }\end{array}$ \\
\hline Tangible & $\begin{array}{l}\text { Tangible } \\
\text { dimension } \\
\text { could help } \\
\text { to achieve } \\
\text { and increase } \\
\text { the info } \\
\text { needs of } \\
\text { customers. }\end{array}$ & $\begin{array}{l}\text { Tangible dimension } \\
\text { could assist on the } \\
\text { customer problem } \\
\text { solving. }\end{array}$ & $\begin{array}{l}\text { Tangible dimension } \\
\text { could assist on the } \\
\text { customer educa- } \\
\text { tion. }\end{array}$ \\
\hline Competence & $\begin{array}{l}\text { Competence } \\
\text { dimension } \\
\text { could help } \\
\text { to achieve } \\
\text { and increase } \\
\text { the info } \\
\text { needs of } \\
\text { customers. }\end{array}$ & $\begin{array}{l}\text { Competence dimen- } \\
\text { sion } \\
\text { could assist on the } \\
\text { customer problem } \\
\text { solving. }\end{array}$ & $\begin{array}{l}\text { Competence di- } \\
\text { mension could } \\
\text { assist on the cus- } \\
\text { tomer education. }\end{array}$ \\
\hline Service & $\begin{array}{l}\text { Info Needs } \\
\text { Quality }\end{array}$ & Problem Solving & $\begin{array}{l}\text { Customer Educa- } \\
\text { tion }\end{array}$ \\
\hline
\end{tabular}

\section{Conclusion}

The application of knowledge for customer roles (kc) to suit unikl mitec student services would in a way instil the level of confidence, trust and loyalty of the students and eventually could capitalise bigger brand name for unikl as a whole. therefore, a study needs to be undertaken in order to show that by enhancing the application of knowledge for customer roles (kc) and service quality model (sq) based, a good vehicle in facilitating the uptrend growth of the university is being driven on a right track eventually. in conclusion, the relationship between the knowledge for customer roles $(\mathrm{kc}$ ) and service quality dimensions (sq) on customer satisfaction are critical to be assessed since those constructs are well connected in the sense that knowledge contributes as important resources for an organization to be able to retain or develop sustainable competitive advantages. moving forward, while the outlook for higher learning institutions sector seems challenging, leveraging on the knowledge impact on customers and staff would be another alternative in providing a full suite of innovative educational products and services to the customers. the customer satisfaction needs to be enhanced, or at least sustained amidst the im- 
pending educational sector dynamics and raising domestic and international competitions. therefore, by putting knowledge and its management as part of paramount business settings, the service quality of student services could be expected to trigger a better provision of services to their valuable customers.

\section{References}

[1] Ove C. Hansemark \& Albinsson, M., 2004, "Customer satisfaction and retention: The experiences of individual employees", Managing Service Quality, Vol. 14, No.1, pp.40-57.

[2] Hoyer, W. D., \& MacInnis, D. J., 2001, "Consumer Behaviour", Journal of Marketing, Vol.58, No.1.

[3] Nasser, R.N., Khoury, B. \& Abouchedid, K., 2008, "University students' knowledge of services and programs in relation to satisfaction", Quality Assurance in Education, Vol. 16, No. 1, pp. 80-97.

[4] Gamage, D.T., Suwanabroma, J., Ueyama, T., Hada, S. \& Sekikawa, E., 2008, "The impact of quality assurance measures on student services at the Japanese and Thailand private universities", Quality Assurance in Education, Vol. 16, No. 2, pp. 181-198.

[5] Tseng, S.M. \& Wu, P.H., 2014, "The impact of customer knowledge and customer relationship management on service quality", International Journal of Quality and Service Sciences, Vol. 6 , Iss. 1, pp. 77-96

[6] Lee, R.P., Naylor, G. \& Chen, Q., 2011, "Linking customer resources to firm success: the role of marketing program implementation”, Journal of Business Research, Vol. 64, No. 4, pp.394-400.

[7] Yoon, V.Y., Hostler, R.E., Guo, Z. \& Guimaraes, T., 2012, “Assessing the moderating effect consumer product knowledge and online shopping experience on using recommendation agents for customer loyalty", Decision Support System, Vol.55, Iss. 4, pp. 883-893.

[8] Davenport, T.H. \& Klahr, P., 1998, "Managing customer support knowledge", California Management Review, Vol.30, Issue 3, 195208.

[9] Rowley, J., 2002, "Reflections on customer knowledge management in e-business", Qualitative Market Research: An International Journal, Vol.5, Iss.4, pp. 268-280.

[10] Gebert, H., Geib, M., Kolbe, L. \& Brenner, W., 2003, 'Knowledgeenabled customer relationship management: integrating customer relationship management and knowledge management concepts', Journal of Knowledge Management, Vol. 7, No.5, pp. 107-123.

[11] Chen, Y. -H., \& Su, C.-T., 2006, "A Kano-CKM Model for Customer Knowledge Discovery", Total Quality Management, Vol. 17, No. 5, pp. 589-608.

[12] Chua Alton, Y.K. \& Banarjee, S., 2013, "Customer knowledge management via social media: a case of Starbuck", Journal of Knowledge Management, Vol. 17, No.2, pp. 237-249.

[13] Davenport, T.H., 2001. How do they know their customers so well? MIT Sloan Management Review: pp.63-73.

[14] Tseng, S.M. \& Wu, P.H., 2014.The impact of customer knowledge and customer relationship management on service quality. International Journal of Quality and Service Sciences, 6(1):77-96.

[15] Bell, S.J. \& Eisingerich, A.B., 2007. The paradox of customer education: Customer expertise and loyalty in the financial services industry. European Journal of Marketing, 41(5/6):466-486.

[16] Tseng, S.M., 2016. The effect of knowledge management capability customer knowledge gaps on corporate performance. Journal of Enterprise Information Management, 29(1):51-71.

[17] Martensson, M., 2000, "A critical review of knowledge management as a management tool", Journal of Knowledge Management, Vol. 4, Iss. 3, pp. 204-216.

[18] Guchait, P., Namasivayam, K. \& Lei, P., 2011, "Knowledge management in service encounters: impact on customers' satisfaction evaluations", Journal of Knowledge Management, Vol. 15, Iss. 3, pp. 513-527.

[19] Meyer, B. \& Sugiyama, K., 2007, "The concept of knowledge in KM: A dimensional model", Journal of Knowledge Management, Vol. 11, No.1, pp. 17-35 